\title{
IRRIGAMETER USE FOR ESTIMATING CROP EVAPOTRANSPIRATION IN PROTECTED ENVIRONMENT ${ }^{1}$
}

\author{
LORENA JÚLIO GONÇALVES ${ }^{2 *}$, CRISTIANO TAGLIAFERRE ${ }^{2}$, MANOEL NELSON DE CASTRO FILHO $^{2}$, DIOGO \\ ULISSES GOMES GUIMARÃES ${ }^{3}$, FELIZARDO ADENILSON ROCHA $^{4}$
}

\begin{abstract}
In the face of climatic adversities associated with water lacking for irrigation, crop cultivation in greenhouses in Brazil has increased significantly, thereby demanding research that makes it possible to estimate crop water demand when grown in these environments. Therefore, the objective of this study was to evaluate the performance of Irrigameters to estimate the evapotranspiration of cowpea grown in protected environment. The experiment was conducted in the experimental area of the State University of Southwest of Bahia (UESB) under protected environment and the cowpea variety used was BRS Guariba. For this study, two Irrigameters were installed for the direct estimation of the daily crop evapotranspiration. Likewise, with the use of an automatic weather, the meteorological data were collected and the crop evapotranspiration (ETc) was estimated using the $\mathrm{Kc}$ values recommended for different phases of the crop. The data collected by the Irrigameter were compared with the data estimated by the Penman-Monteith method, as well as with Radiation and Blaney Criddle methods at one-, two- and three-day intervals. The results show that all the methods were efficient and accurate at estimating ETc at all studied intervals.
\end{abstract}

Keywords: Climatic variables. Irrigation management. Cowpea beans. Water Consumption.

\section{USO DO IRRIGÂMETRO NA ESTIMATIVA DA EVAPOTRANSPIRAÇÃO DA CULTURA EM AMBIENTE PROTEGIDO}

RESUMO - Diante das adversidades climáticas associadas à falta de água para irrigação o cultivo em ambiente protegido no Brasil tem apresentado crescimento significativo, que ressalta a demanda de pesquisas que possibilitem estimar precisamente a necessidade de água pelas culturas quando cultivadas nesses ambientes. Assim sendo, objetivou-se avaliar o desempenho do Irrigâmetro para estimativa da evapotranspiração da cultura do feijão caupi em ambiente protegido. A pesquisa foi conduzida na área experimental da Universidade Estadual do Sudoeste da Bahia (UESB), em ambiente protegido e a variedade do feijão caupi utilizada foi a BRS Guariba. Para este estudo instalaram-se dois Irrigâmetros para estimativa direta da evapotranspiração diária da cultura. Da mesma forma, com o uso de uma estação meteorológica automática, coletaram-se os dados meteorológicos e estimou-se a evapotranspiração da cultura (ETc), usando os valores de Kc recomendados para as diversas fases da cultura. Os dados obtidos no Irrigâmetro foram comparados com os dados obtidos pelo método de Penman-Monteith, fazendo-se o mesmo para o método da Radiação e Blaney Criddle, em intervalos de tempo um, dois e três dias. Os resultados mostram que todos os métodos foram eficientes e precisos na estimativa da ETc, em todos os intervalos de tempo estudados.

Palavras-chave: Variáveis climáticas. Manejo de irrigação. Feijão caupi. Consumo hídrico.

\footnotetext{
${ }^{*}$ Corresponding author

${ }^{1}$ Received for publication in $07 / 16 / 2018$; accepted in $02 / 28 / 2019$.

Paper extracted from scientific initiation project of the first author.

${ }^{2}$ Laboratory of Agricultural Hydraulics and Irrigation and Drainage, Universidade Estadual do Sudoeste da Bahia, Vitória da Conquista, BA, Brazil; lorenagoncalves.agro@gmail.com - ORCID: 0000-0002-0793-9630, tagliaferre@yahoo.com - ORCID:0000-0003-4776-473X, manoel_mrr@hotmail.com - ORCID: 0000-0001-6783-9861.

${ }^{3}$ Agronomist Engineer, Vitória da Conquista, BA, Brazil; diogoulisses1@hotmail.com - ORCID: 0000-0001-8706-4725.

${ }^{4}$ Department of Environmental Engineering, Instituto Federal da Bahia, Vitória da Conquista, BA, Brazil; felizardoarocha@ufcg.edu.br - ORCID: 0000-0001-6410-5176.
} 


\section{INTRODUCTION}

The study of water loss evapotranspiration is indispensable for irrigation planning, especially in regions characterized by great spatial and temporal variability of precipitation, as in the arid and semiarid areas of Northeastern Brazil.

Thus, information about reference evapotranspiration, which leads to estimation of crop evapotranspiration, has become an important tool in the management of irrigation (ARAÚJO; COSTA; SANTOS, 2007). According to Souza et al. (2009) evapotranspiration surveys provide information on the amount of water consumed by plants, providing data for water management and for the design of irrigation systems.

In the face of climatic adversities, cultivation in a protected environment in Brazil showed significant growth, mainly in the production of vegetables and flowers which have high economic value (REIS et al., 2012). Cultivation in a controlled environment (greenhouse) is a step forward in the tendency to control environmental variables and protect the crop from chance, aiming at optimizing and maximising agricultural production.

The adoption of protected cultivation has expanded rapidly across the world (SILVA; SILVA; PAGIUCA, 2014). Rebouças et al. (2015) reported that in the 1990s, global estimates indicated that greenhouses occupied an area of 716 thousand hectares; as early as 2010 , there were 3.7 million hectares of plants grown under greenhouse conditions, most of which consisted of vegetables.

Depending on the various methods available for the estimation of evapotranspiration, choosing the most appropriate depends on the availability of meteorological data, the level of precision required, the purpose and cost of equipment acquisition (OLIVEIRA et al., 2011a). This has led researchers to develop simpler alternative methods to determine evapotranspiration for irrigation management, with the goal of reducing costs, ease of handling, scientific accuracy and consistency.

In this sense, the Irrigameter is the technology that was developed at the Federal University of Viçosa (UFV) in order to make irrigators more practical. The Irrigameter is an apparatus that combines the method of estimation of evapotranspiration with the availability of water in the soil for the crop, allowing inclusion of the effectiveness of the rain guage with irrigation management. It is composed of an evaporimeter with a rain gauge, which can be adjusted to directly supply the reference evapotranspiration of the crop at any stage of its development (OLIVEIRA; RAMOS, 2008). In order for the Irrigameter to work, adjustments must be made according to soil type, crop and characteristics of the irrigation system used. The equipment provides the consumption by the crop, the time of irrigation and the moment of irrigation without the need to perform calculations.

Several studies have already been conducted with the Irrigameter in diverse crops and regions of the country, among them are the works developed by Tagliaferre et al. (2012), Tagliaferre (2010) and Oliveira et al. (2011b). However, few studies have been conducted to test its applicability in a greenhouse, which requires more advanced studies. Thus, the objective of this study was to evaluate the performance of the Irrigameter for estimating the evapotranspiration of cowpea crop in a greenhouse.

\section{MATERIAL AND METHODS}

The experiment was conducted in the experimental area of the State University of Southwest Bahia (UESB), located in the municipality of Vitoria da Conquista-BA, situated at the coordinates $14^{\circ} 51^{\prime}$ latitude South, $40^{\circ} 50^{\prime}$ longitude west and with altitude of 876 meters. The climate of the region varies from subhumid to semiarid with minimum temperatures ranging from 9 to $15{ }^{\circ} \mathrm{C}$ in the colder month (July), while in summer the maximum recorded temperatures fluctuate from 22 to $30{ }^{\circ} \mathrm{C}$ in the warmer month (January) (TAGLIAFERRE et al., 2012). The average annual temperature varies from 19.5 to $20.5{ }^{\circ} \mathrm{C}$, average annual air relative humidity varies from 70 to $85 \%$, with average annual rainfall around $733.9 \mathrm{~mm}$.

For this study, two Irrigameters were installed inside a greenhouse that contained 21 lysimeters of drainage, with dimensions of $1.0 \mathrm{~m}$ of width, $1.40 \mathrm{~m}$ of length and $0.80 \mathrm{~m}$ of depth. Lysimeters were used for the cultivation of cowpea in experiments involving irrigation, and in this way the crop received all the cultivation treatments indicated and all needed to supply the water requirement.

Daily measurements of climatic variables were made by means of an automatic Agrometeorological station installed in the greenhouse. The data obtained were organized in a computational program to estimate the reference evapotranspiration (ETo) by the methods of Penman Monteith-FAO-56, radiation and Blaney Criddle through ETc with the use of Equation 1.

To estimate crop evapotranspiration (Equation 1), the cycle was divided into developmental subperiods, as proposed by Allen et al. (2006): Initial (I) - from planting to $10 \%$ soil cover; growth (II) - from the end of the initial stage to $80 \%$ of the soil cover; reproductive-flowering and grain filling (III) - 80\% soil cover until maturation begins; End (IV) - from the beginning of maturation to the harvest. The coefficients of the crop were considered according to the phenological phase, being 0.8 for the initial development; 1.0 for vegetative development; 1.2 for flowering and 1.0 for the formation of grains (BASTOS et al., 2008). 


$$
\text { ETc }=\text { ETo } \times \text { Kc }
$$

wherein:

ETc: evapotranspiration of the crop $\mathrm{mm} \mathrm{day}^{-1}$;

ETo: reference evapotranspiration $\mathrm{mm} \mathrm{day}^{-1}$; and

Kc: coefficient of determination of the stage of crop development.

In addition, daily readings of the evapotranspiration were performed in the two Irrigameters using the water level inside the evaporator, which is a container in the form of a cone that maintains water with surface exposed to the atmosphere. The height of the water level inside can be modified so that the surface area exposed to the atmosphere is altered, allowing for the estimation of ETc (OLIVEIRA; RAMOS, 2008). The evaporator was adjusted over the cowpea crop cycle according to the values presented in Figure 1.

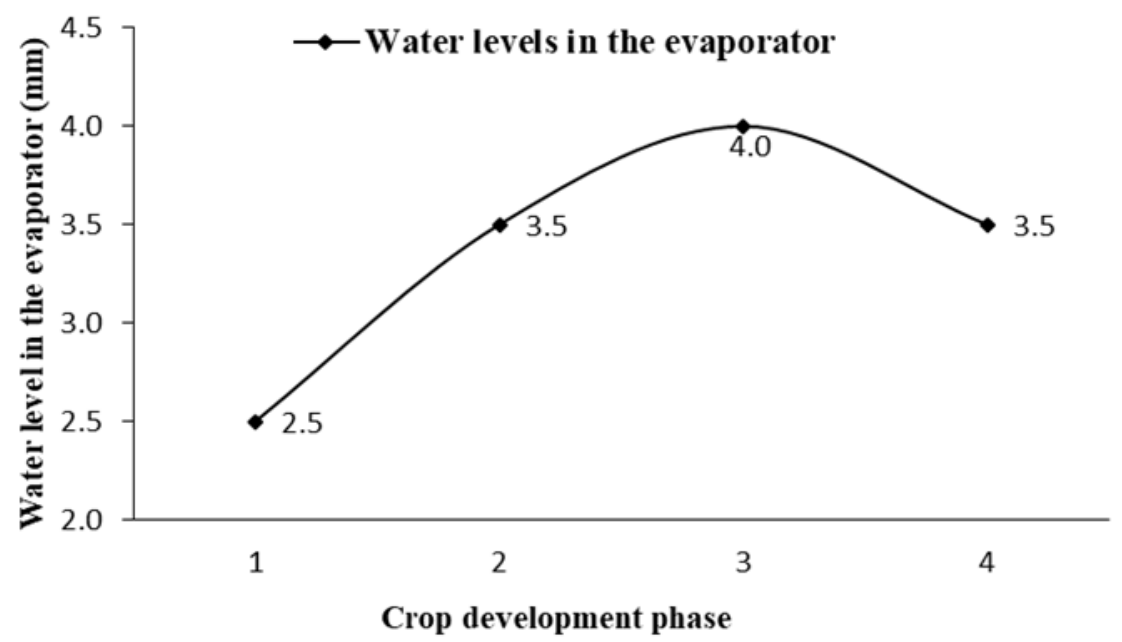

Figure 1. Water levels in the evaporator according to the stage of crop development.

In order to evaluate the Irrigameter performance, the ETc estimated by the equipment was compared with those determined by the Penman Monteith-FAO-56, Radiation and Blaney-Criddle methods during the cowpea crop cycle. The Penman Monteith-FAO-56 method was adopted as standard. The methodology adopted for comparing the results was proposed by Allen (1986), and is based on estimation of the standard error (EEP), calculated by Equation (2). The analysis of the performance of each method was also based on the parameters of the simple linear regression equation ( $\mathrm{a}$ and $\mathrm{b}$ ), the coefficient of determination $\left(r^{2}\right)$, the concordance index (d) according to Equation 3 and the performance index (c) obtained by multiplication of the correlation coefficient (r) with the value of $d$. The best alternative is the one with the highest value of $c$, lowest EEP and b near unity.

$$
\mathrm{EEP}=\left(\frac{\sum(\mathrm{y}-\overline{\mathrm{y}})^{2}}{\mathrm{n}-1}\right)^{\frac{1}{2}}
$$

wherein:

EEP: standard error estimate, $\mathrm{mm} \mathrm{day}^{-1}$;

$y:$ reference evapotranspiration estimated by the standard method, mm day $^{-1}$;

$\bar{y}$ : reference evapotranspiration obtained by the method considered, $\mathrm{mm}_{\text {day }}{ }^{-1}$; $\mathrm{n}$ : number of observations.

$$
\mathrm{d}=\frac{\sum_{\mathrm{i}=1}^{\mathrm{n}}(\mathrm{Pi}-\mathrm{Oi})^{2}}{\sum_{\mathrm{i}=1}^{\mathrm{n}}[(|\mathrm{Pi}-\overline{\mathrm{O}}|)+(|\mathrm{O} \mathrm{i}-\overline{\mathrm{O}}|)]^{2}}
$$

where:

$\mathrm{d}$ : concordance or adjustment index;

Pi: reference evapotranspiration obtained by the method considered, $\mathrm{mm}_{\text {day }}{ }^{-1}$;

Oi: Reference evapotranspiration obtained by the standard method, mm day $^{-1}$

Ö: Mean ETo values obtained by the standard method, mm day ${ }^{-1}$.

\section{RESULTS AND DISCUSSION}

The parameters of the regression equation, coefficient of determination, correlation coefficient, standard error estimate, concordance index, and the performance or confidence index, obtained from the correlations between the values of ETc estimated by the Irrigameter and by the other methods studied in relation to the Penman-Monteith-FAO 56 method, in time intervals of one, two and three days, are presented in Table 1. 
Table 1. Regression parameters ( $a$ and $b$ ), coefficient of determination $\left(r^{2}\right)$, correlation coefficient ( $\left.r\right)$, standard error estimate (EEP), concordance index (d) and index of confidence or performance (c) for the intervals of one, two and three days.

\begin{tabular}{|c|c|c|c|c|c|c|c|c|c|}
\hline Methods & $\mathrm{a}$ & $\mathrm{b}$ & $r^{2}$ & EEP & $\mathrm{r}$ & $\mathrm{d}^{*}$ & $\mathrm{c}^{* *}$ & Classification** & $\operatorname{ETc}\left(\mathrm{mm} \mathrm{d}^{-1}\right)$ \\
\hline \multicolumn{10}{|c|}{ Daily } \\
\hline FAO 56 PM & & & & & & & & & 3.06 \\
\hline Radiation & 1.018 & -0.005 & 0.940 & 0.260 & 0.970 & 0.98 & 0.95 & Optimum & 3.47 \\
\hline Blaney-Criddle & 1.376 & -0.739 & 0.958 & 0.630 & 0.979 & 0.93 & 0.91 & Optimum & 3.11 \\
\hline Irrigameter & 1.143 & -0.093 & 0.809 & 0.670 & 0.899 & 0.91 & 0.82 & Very good & 3.40 \\
\hline \multicolumn{10}{|c|}{ Two days } \\
\hline FAO 56 PM & & & & & & & & & 3.06 \\
\hline Radiation & 1.354 & -0.674 & 0.959 & 0.420 & 0.979 & 0.93 & 0.91 & Optimum & 3.47 \\
\hline Blaney-Criddle & 1.020 & -0.013 & 0.953 & 0.160 & 0.976 & 0.98 & 0.96 & Optimum & 3.11 \\
\hline Irrigameter & 1.142 & -0.092 & 0.808 & 0.300 & 0.899 & 0.95 & 0.85 & Very good & 3.40 \\
\hline \multicolumn{10}{|c|}{ Three days } \\
\hline FAO 56 PM & & & & & & & & & 3.06 \\
\hline Radiation & 1.320 & -0.574 & 0.958 & 0.320 & 0.979 & 0.93 & 0.91 & Optimum & 3.47 \\
\hline Blaney-Criddle & 1.019 & -0.004 & 0.960 & 0.111 & 0.980 & 0.98 & 0.96 & Optimum & 3.11 \\
\hline Irrigameter & 1.142 & -0.092 & 0.808 & 0.251 & 0.899 & 0.95 & 0.85 & Very good & 3.40 \\
\hline
\end{tabular}

**Camargo \& Sentelha (1997); *Willmott, et al. (1985).

The results obtained daily showed that the radiation method presented the best performance index $(c=0.95)$ and concordance index $(0.98)$, being classified as "optimum". Still with "optimum" performance was the Blaney-Criddle method; however, the indexes "c" and "d" were lower, 0.91 and 0.93 , respectively.

The Irrigameter demonstrated "Very Good" performance for daily readings, overestimating by $0.34 \mathrm{~mm}$ day $^{-1}$ the ETc when obtained by the standard method. The Radiation method, which presented "Optimum" performance, overestimated ETc by $0.41 \mathrm{~mm} \mathrm{day}^{-1}$, a result superior to that of the Irrigameter. Tagliaferre et al. (2011) verified that the Radiation method overestimated the reference evapotranspiration compared to that obtained by the lysimeter. Lunardi; Lunardi; Cavati (1999) also verified this same behavior in relation to ETo with the use of the Radiation method in Botucatu - SP. However, in this study, despite overestimating the ETc, the performance of all the methods was satisfactory, but since the Irrigameter is associated with simplicity and practicality, and does not require a meteorological station, it makes it more suitable to assist in Irrigation management. Oliveira et al. (2008) when evaluating the performance of the Irrigameter in the estimation of reference evapotranspiration verified that the Irrigameter presented satisfactory performance in estimating the ETo intervals of one, three, five and seven days, indicating that it is suitable for use in water management in irrigated agriculture.

On the two-day scale, the radiation method showed a lower performance index "c" and concordance " $\mathrm{d}$ " compared to the daily scale, but presented a better precision (accuracy) index " $r$ ". The Blaney-Criddle method presented an inverse behavior, increasing the coefficients of concordance and performance, and reducing the precision index.

Regarding the estimation of standard error, the highest value found for the daily scale was 0.670 $\mathrm{mm}$ day $^{-1}$, in the Irrigameter method. However, this value was reduced for the two and three day scales, with values of 0.30 and $0.25 \mathrm{~mm} \mathrm{day}^{-1}$, respectively. These values are lower than those of the radiation method, 0.42 and $0.32 \mathrm{~mm} \mathrm{day}^{-1}$.

The grouping (clustering) of ETc at intervals of two and three days, respectively, resulted in an increase in the concordance index (d) and confidence Index (c), for the Blaney-Criddle and Irrigameter methods, compared to the daily interval, but the same did not occur for the Radiation method. For the time scales studied, the Irrigameter, as well as the other methods, proved to be reliable in estimating the ETc associated with low cost, high practicality, and dispensing calculations, thus making it suitable for irrigation management.

Figure 2 presents the behavior of the daily evapotranspiration of the crop, estimated by the Irrigameter (2A), Radiation (2B) and Blaney-Criddle (2C) compared to the standard Penman-MonteithFAO 56 method. 
A

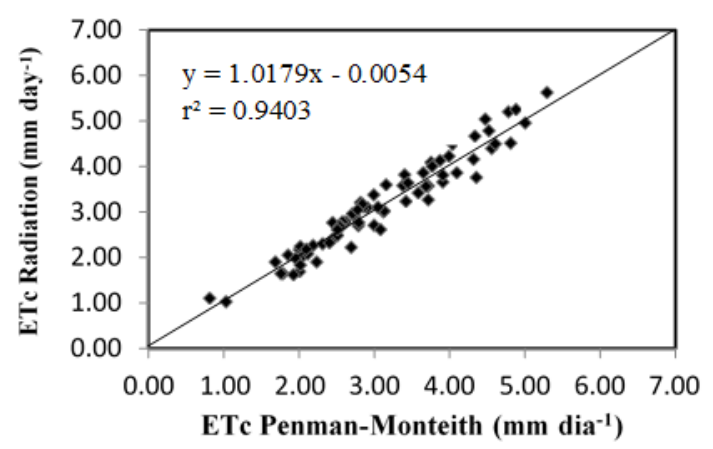

B

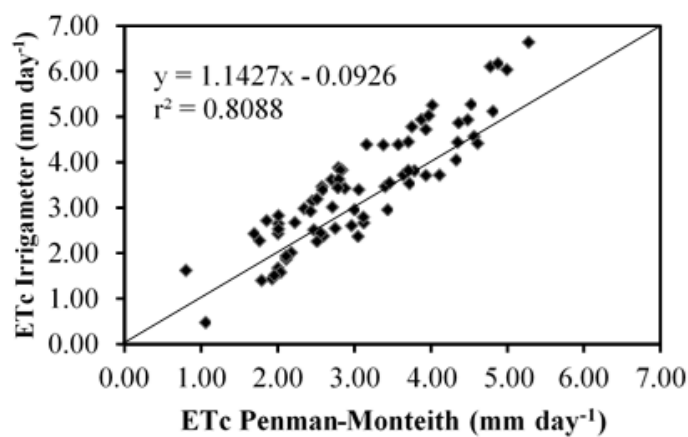

$\mathrm{C}$

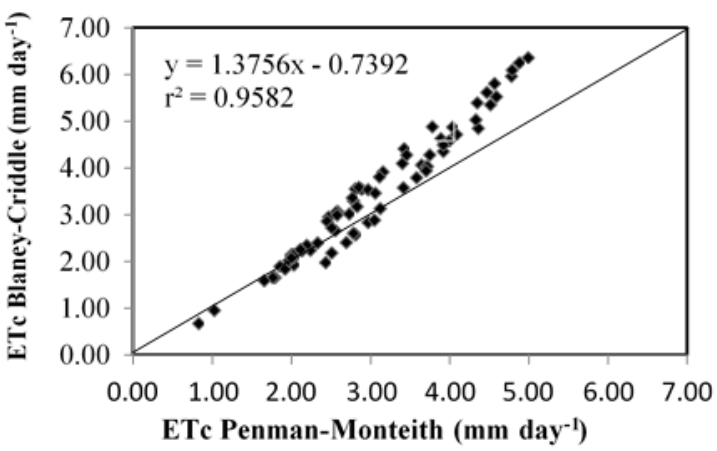

Figure 2. Behavior of daily evapotranspiration determined by the method of Radiation (A), Irrigameter (B) and BlaneyCriddle (C) compared to the standard method of Penman-Monteith - FAO 56.

It can be observed in Figure 2 that the ETc determined by the Radiation method, practically follows the 1:1 line of values presenting better performance than the other methods considered in this study, based on the Penman-Monteith - FAO 56 method. However, the Irrigameter method, despite having a greater dispersion of the ETc values, shows that the values follow the 1: 1 line, indicating that the values obtained by this method are well correlated with those of the standard method, FAO 56. Tagliaferre et al. (2011), evaluating the performance of the Irrigameter and other methods of reference evapotranspiration estimation in the municipality of Guanambi-BA, obtained coefficients of determination for daily scales of 0.88 for the Radiation method and of 0.57 and 0.54 for the Irrigameter method with water levels of 3 and $4 \mathrm{~cm}$ in the evaporator.

Figure 3 shows the behavior of crop evapotranspiration, estimated by the Irrigameter (3A), Radiation (3B) and Blaney-Criddle (3C), compared to the Penman-Monteith-FAO 56 method, in the two-day interval.

For the two-day period (Figure 3), the Blaney -Criddle method presented better data distribution in relation to the standard FAO 56 method, compared to the other methods. The Radiation and Irrigameter methods also showed good results in the distribution of ETc data in relation to the method of PenmanMonteith - FAO 56. The data dispersion in relation to the FAO 56 standard method may have occurred due to the climatic variables that are used in each method. Within the greenhouse, due to the diffusivity of the cover and the conditions of temperature, air relative humidity and the reduction of winds, the evapotranspiration tends to reduce (REIS; SOUZA; AZEVEDO, 2009; GUISELINI et al., 2010; OLIVEIRA et al., 2014). Oliveira et al. (2017) when evaluating the reference evapotranspiration in a protected environment through a Class A tank (TCA) and a meteorological station installed in the area, correlated with the ETo of the external environment calculated by different estimation methods, verified that the ETo of the covered area corresponded to $77.8 ; 75.0$ and $82.4 \%$ of the ETo obtained by the Penman-Monteith methods, TCA and Jensen and Haise, respectively; and 105 and $131.3 \%$ of the ETo obtained by the methods of Hargreaves and Samani and Makkink, respectively. Reis et al. (2012) stated that agricultural cultivation in greenhouses allows protection of plants against high temperatures and higher intensity of solar radiation, during all its growth, thus reducing evapotranspiration. According to Oliveira et al. (2017), protected environments provide micrometeorological modifications in relation to the external environment, favoring the processes of reflection and absorption of the solar rays and consequently, reduction of solar radiation. 
A

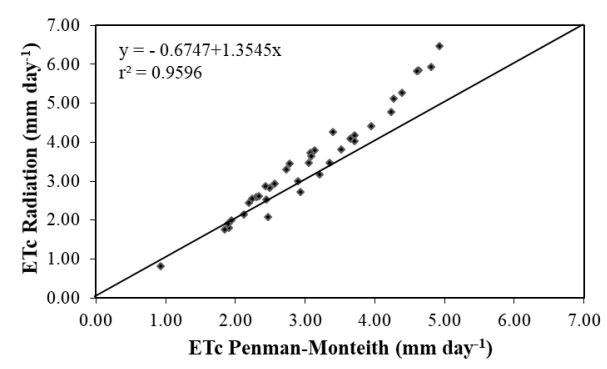

B

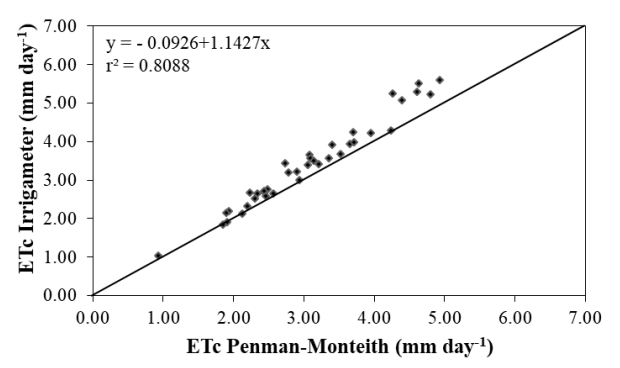

$\mathrm{C}$

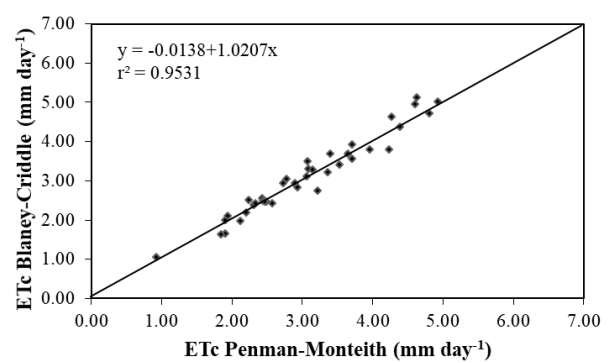

Figure 3. Behavior of crop evapotranspiration, determined by the method of Radiation (A), Irrigameter (B) and BlaneyCriddle (C) compared to the method of Penman-Monteith FAO 56, within an interval of two days.

Figure 4 shows the crop evapotranspiration behavior estimated by an Irrigameter (4A), Radiation (4B) and Blaney-Criddle (4C), compared to the Penman-Monteith - FAO 56 method, within three days.

The distribution of ETc values for the threeday interval was similar to that observed for the twoday interval. By observing the grouping (clustering) of ETc values in longer periods for the Blaney-

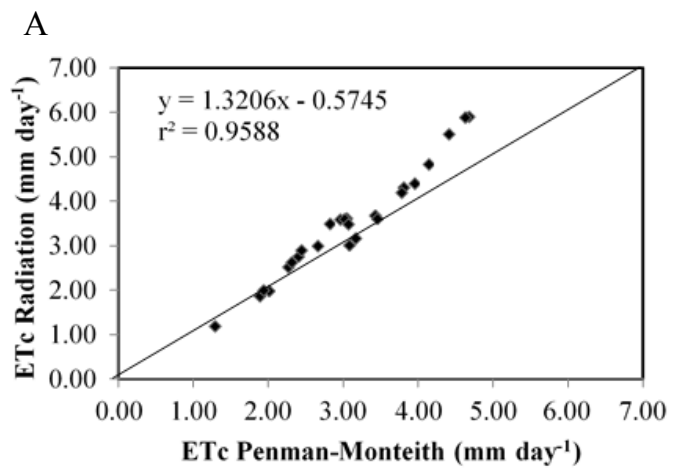

Criddle method, according to the FAO 56 standard, ETc estimation tends to improve. However, the same does not occur for the Irrigameter method that presented the same behavior, in the three evaluation time intervals. For the same purpose of the study, Tagliaferre et al. (2012), found coefficients of determination of $0.57,0.74$ and 0.80 for reading periods, daily, three and five days, respectively.

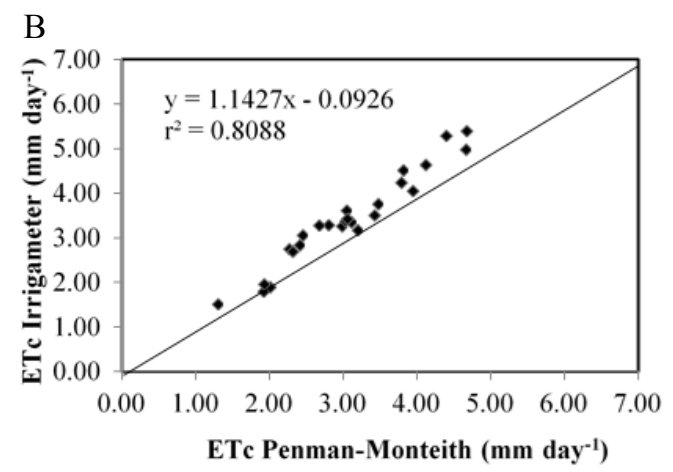

$\mathrm{C}$

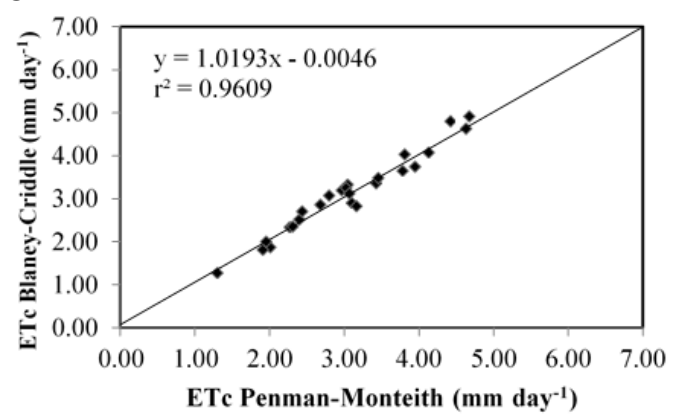

Figure 4. Behavior of crop evapotranspiration, determined by the method of Radiation (A), Irrigameter (B) and BlaneyCriddle (C) compared to the method of Penman-Monteith - FAO 56, in the three-day interval. 


\section{CONCLUSION}

The Irrigameter presents a satisfactory performance to estimate the ETc in the time intervals of one, two and three days, for the management of irrigation in a protected environment.

The Blaney-Criddle and Radiation methods showed optimum performance at time intervals one, two and three days.

The Blaney-Criddle method was the closest approach to the standard method of PenmanMonteith-FAO 56, overestimating the ETc by only $0.05 \mathrm{~mm}$ day $^{-1}$.

\section{REFERENCES}

ALLEN, R. G. A Penman for all seasons. Journal of Irrigation and Drainage Engineering, v. 112, n. 4, p. 348-386, 1986.

ALLEN, R. G. et al. Evapotranspiración del cultivo: guías para la determinación de los requerimientos de água de los cultivos. Roma: FAO, 2006. 298 p.

ARAÚJO, W. F.; COSTA, S. A. A.; SANTOS, A. E. dos. Comparação entre métodos de estimativa da evapotranspiração de referência (ETo) para Boa Vista, RR. Caatinga, v. 20, n. 4, p. 84-88, 2007.

BASTOS, E. A. et al. Evapotranspiração e coeficiente de cultivo do feijão-caupi no Vale do Gurguéia, Piauí. Irriga, v. 13, n. 2, p. 182-190, 2008.

GUISELINI, C. et al. Manejo da cobertura de ambientes protegidos: radiação solar e seus efeitos na produção da gérbera. Revista Brasileira de Engenharia Agrícola e Ambiental, v. 14, n. 6, p. $645-652,2010$.

LUNARDI, M. A.; LUNARDI, D. M. C.; CAVATI, N. Comparação entre medidas evapotranspirométricas e metodológicas da FAO, na determinação da evapotranspiração de referência. Irriga, v. 4, n. 1, p. 52-66, 1999.

OLIVEIRA, R. A.; RAMOS, M. M. Manual do irrigâmetro. 1. ed. Viçosa; MG: UFV, 2008. 144 p.

OLIVEIRA, R. A. et al. Desempenho do irrigâmetro na estimativa da evapotranspiração de referência. Revista Brasileira de Engenharia Agrícola e Ambiental, v. 12, n. 2, p. 166-173, 2008.
OLIVEIRA, E. M. et al. Desempenho do irrigâmetro no manejo da irrigação no perímetro irrigado do Jaíba, MG, Brasil. Revista Ambiente \& Água, v. 6, n. 1, p. 157-164, 2011a.

OLIVEIRA, E. M. et al. Análise do coeficiente e o desempenho do Irrigâmetro e a influência dos elementos do clima na estimativa da evapotranspiração. Revista Engenharia na Agricultura, v. 19, n. 4, p. 348-360, 2011 b.

OLIVEIRA, E. C. et al. Evapotranspiração da roseira cultivada em ambiente protegido. Revista Brasileira Engenharia Agrícola e Ambiental, v. 18, n. 3, p. 314-321, 2014.

OLIVEIRA, G. M. et al. Estimativa da evapotranspiração de referência para ambiente protegido. Irriga, v. 1, Sup., p. 21-30, 2017.

REBOUÇAS, P. M. et al. Radiação solar e temperatura do ar em ambiente protegido. Revista Agrogeoambiental, v. 7, n. 2, p. 115-125, 2015.

REIS, L. S.; SOUZA, J. L.; AZEVEDO, C. A. V. de. Evapotranspiração e coeficiente de cultivo do tomate caqui cultivado em ambiente protegido. Revista Brasileira de Engenharia Agrícola e Ambiental, v. 13, n. 3, p. 289-296, 2009.

REIS, L. S. et al. Componentes da radiação solar em cultivo de tomate sob condições de ambiente protegido. Revista Brasileira de Engenharia Agrícola e Ambiental, v. 16, n. 7, p. 739-744, 2012.

SILVA, B. A.; SILVA, A. R.; PAGIUCA, L. G. Cultivo Protegido: Em busca de mais eficiência produtiva. Revista Técnica Hortifruti Brasil, p. 1018, 2014. Disponível em: $<$ http://cepea.esalq.usp.br/ hfbrasil/edicoes/132/mat_capa.pdf $>$. Acesso em: 10 dez. 2017.

SOUZA, M. S. M. et al. Evapotranspiração do maracujá nas condições do vale do Curu. Caatinga, v. 22 , n. 2 , p. 11-16, 2009.

TAGLIAFERRE, $\mathrm{C}$. et al. Desempenho do Irrigâmetro no manejo da água de irrigação na cultura do feijoeiro. Revista Caatinga, v. 23, n. 3, p. $110-117,2010$

TAGLIAFERRE, C. et al. Uso do Irrigâmetro para estimar a evapotranspiração de referência com base no método do lisímetro de lençol freático constante. Engenharia na Agricultura, v. 19, n. 2, p. 152-163, 2011. 
TAGLIAFERRE, C. et al. Desempenho do Irrigâmetro e de métodos de estimativa da evapotranspiração de referência para o município de Guanambi-BA. Engenharia na Agricultura, v. 20, n. 6 , p. $544-553,2012$. 